\title{
REDISCOVERY OF AULACIDEA KIEFFERI COTTE, 1915 (HYMENOPTERA, CYNIPIDAE), WITH REDESCRIPTION OF THE ADULT AND TERMINAL LARVA
}

\author{
J. L. Nieves-Aldrey*
}

\begin{abstract}
Aulacidea kiefferi Cotte, 1915, a cynipid species that induces gall formation on the plant Carthamus lanatus L., known only from a single old record from France, was recently re-discovered in a locality south-east of Madrid (central Spain). In this study, we re-describe the species, including a new description of the male and the terminal larva. We transfer the species to the genus Phanacis, and provide a key for the identification of the related West European Phanacis species. P. kiefferi might potentially be used as an agent for the biological control of the host plant, $C$. lanatus, the saffron or distaff thistle, a harmful weed native to the Mediterranean Region, with a virtually worldwide current distribution.
\end{abstract}

Key words: Aylacini, Phanacis, Carthamus lanatus, gall-wasps, larvae, galls, weed control, Madrid.

\section{RESUMEN}

\section{Redescubrimiento de Aulacidea kiefferi Cotte, 1915 (Hymenoptera, Cynipidae), con redescripción del adulto y del último estado larval}

Aulacidea kiefferi Cotte, 1915, un cinípido que induce la formación de agallas en la planta Carthamus lanatus L., conocido tan solo por una única antigua cita de Francia, se ha redescubierto en el centro de España, en el sureste de la Comunidad de Madrid. En este estudio se redescribe la hembra adulta y la agalla de la especie, incluyendo una descripción nueva del macho y del último estado larval. Se transfiere la especie al género Phanacis, y se aporta una clave de identificación de las especies europeas afines del género Phanacis. P. kiefferi puede potencialmente utilizarse en el control biológico de su planta hospedadora, el cártamo lanoso, una maleza invasora nociva, nativa de la región mediterránea, que presenta en la actualidad una distribución virtualmente cosmopolita.

Palabras clave: Aylacini, Phanacis, Carthamus lanatus, avispas gallícolas, larvas, agallas, control de malezas, Madrid.

* Museo Nacional de Ciencias Naturales, departamento de Biodiversidad y Biología Evolutiva. José Gutiérrez Abascal 2, 28006 MADRID, SPAIN. e-mail: aldrey@mncn.csic.es 


\section{Introduction}

Cynipids of the tribe "Aylacini" (Hymenoptera: Cynipoidea, Cynipidae), also known as herb gall wasps, induce galls on herbs and shrubs of the families Asteraceae, Papaveraceae, Lamiaceae, Valerianaceae and Rosaceae. The greatest species richness within this group of cynipids is found in the West Palaearctic region, and it is thought that the centre of radiation of herb gall wasps occurred in the area surrounding the Black Sea (Liljeblad \& Ronquist 1998; Ronquist \& Liljeblad 2001; NievesAldrey, 2001; Melika, 2006). Approximately 160 species of Aylacini are known worldwide, with 125 of them recorded from the Palaearctic (Liljeblad, 2002). The Western European genera of Aylacini were revised by Nieves-Aldrey (1994), who later revised all species found in the Iberian Peninsula (Nieves-Aldrey, 2001). The only other recent review on this group is from Melika (2006). Morphological and molecular studies of Cynipidae phylogeny have shown that the currently classified "Aylacini" group is an artificial and non-monophyletic assemblage of different lineages (Liljeblad \& Ronquist, 1998; Nylander et al, 2004). Clearly, the classification of these genera need re-examination.

One of the most species-rich Aylacini genera is the species complex Phanacis/Timaspis. The group includes about 25 species, most of them distributed in the Palaearctic, particularly in Europe and Central Asia (Nieves-Aldrey, 2001; Liljeblad, 2002; Melika, 2006). Recently the first Phanacis species from the Afrotropical region has been described (Melika \& Prinsloo 2007). Timaspis has been alternatively synonymized with Phanacis by Eady \& Quinlan (1963), resurrected by NievesAldrey (1994), and returned to synonymy by Melika (2006). This instability reflects the taxonomic complexity of these two genera. A thorough revision of the species complex that incorporates molecular phylogenetic data is still necessary.

The different species of Phanacis predominantly induce galls on plants of the Asteraceae family, particularly in species of Centaurea, with the exception of two species, which produce galls in Phlomis (Lamiaceae) and Eryngium (Apiaceae). The list of Western European species of Phanacis (sensu stricto) includes eight species (Table 1).

Aulacidea kiefferi was described by Cotte (1915) (although this author attributed the description to Kieffer), who found the gall on Kentrophyllum lanatum (L.) DC. (= Carthamus lanatus L.), on the Mediterranean coast of France. The species has not
Table 1.- List of Western European species of Phanacis Foerster, 1860 (sensu stricto) and their host plant genera (species included in Timaspis of authors excluded).

Tabla 1.- Lista de especies de Phanacis Foerster, 1860 (sensu stricto) de Europa occidental y sus géneros de plantas hospedantes (se excluyen las especies incluidas en Timaspis de autores).

\begin{tabular}{lc}
\hline Phanacis species & Host plants \\
\hline P. caulicola (Hedicke, 1939) & Picris \\
P. centaureae (Foerster, 1860) & Centaurea \\
P. zwoelferi Nieves-Aldrey, 1995 & Silybum \\
P. hypochoeridis (Kieffer, 1887) & Hypochoeris \\
P. helminthiae (De Stefani, 1902) & Picris \\
P. comosae Nieves-Aldrey, 2008 & Picris \\
P. taraxaci (Ashmead, 1897) & Taraxacum \\
P. kiefferi (Cotte, 1915) & Carthamus \\
\hline
\end{tabular}

been observed in the more than 90 years since its description. Unfortunately the type material of this species has not been found and it is therefore excluded from this revision. The species has more recently been found near Madrid (Central Spain) and we assign it to the genus Phanacis. The objective of the present study is to re-describe A. kiefferi with the material recently collected from Spain. We aim also to provide a key for the identification of the allied Western European Phanacis species, and to describe the adult male and the mature larvae of the species.

\section{Materials and Methods}

Studied material was reared from galls collected in the field in Spain. Adults emerged from galls in rearing cages under laboratory conditions. Freshly collected galls were dissected and their contents (larvae and adults) identified and photographed. Adult insects were dissected in $70 \%$ ethanol, air dried, mounted on a stub and coated with gold. Micrographs of several standardized views were taken with a scanning electron microscope FEI QUANTA 200 using a high vacuum technique. Forewings were mounted in Euparal on slides, and examined under a stereomicroscope. Larvae were transferred directly from absolute alcohol onto an SEM-stub, and were examined at a low vacuum without fixation or coating. Larval mandibles were dissected, mounted, and observed similarly to the morphological parts of adult, following the proto- 
col described in Nieves-Aldrey et al. (2005). Images of forewings, adult habitus, galls, and dissected galls were taken with a Nikon digital camera attached to a Leica stereomicroscope. Terminology of the morphological structures and abbreviations follows Ronquist \& Nordlander (1989), Ronquist (1995), Nieves-Aldrey (2001) and Liljeblad (2002). SEM pictures of adult and larva will be deposited in Morphbank (http://morphbank.com).

Phanacis kiefferi (Cotte, 1915) nov. comb.

Aulacidea kiefferi Cotte, 1915. Annals Mus. Hist. Nat. Marseille, $15(2): 25$

Material studied: $2 \sigma^{\pi}, 28$ 우, SPAIN, Madrid, Arganda del Rey, Dehesa El Carrascal, 20/I/2008, ex gall Carthamus lanatus (Asteraceae) (09/XI/2007) J. L. Nieves leg (dry mounted); other material (preserved in ethanol): $10^{\pi}, 23$ 우 ㅇ. All materials deposited in the collections of the Museo Nacional de Ciencias Naturales, Madrid.

This species was described from material reared from galls on Kentrophyllum lanatum (= Carthamus lanatus) collected in Cogolin (Var, south-eastern of France).

The original insect description is relatively poor, and refers only to a few morphological characteristics. Furthermore, although the description was illustrated with a habitus figure, many important diagnostic characters are not discernibly illustrated. The species was not further recorded until its rediscovery in Spain, and we now present a complete re-description of the adults based on SEM image analysis, including the first description of the male and the terminal larva.

\section{REDESCRIPTION}

Habitus: female (Fig. 4A)

Body length $2.4 \mathrm{~mm}$ (range $2-2.8 \mathrm{~mm} ; \mathrm{N}=15$ ) for females; $2 \mathrm{~mm}$ (range 1.8-2.2; $\mathrm{N}=2$ ) for males. Body coloration black; the first six antennal segments and the legs, excepting the proximal half of the coxae, light brown or dirty yellow. Forewing hyaline and veins brown, excepting parts of the R1, subcostal yellowish or reddish-yellow.

Head

Head, dorsal view, about twice as wide as long, slightly wider than mesosoma; POL 1.4 times OOL, posterior ocellus separated from inner orbit of eye by about 2.6 times its diameter. Genae slightly expanded behind eyes.

Head anterior view (Fig. 1A) more or less rounded, 1.2 times as wide as high; lower face sparsely pubescent; facial striae radiating from clypeus extended close to ventral margin of compound eyes and laterally to the ventral margin of antennal toruli; the facial striae are absent medially above clypeus. Upper face and vertex almost bare and with reticulate sculpture. Ocellar plate slightly raised; the median ocellus separated from the anterior margin of the vertex by a distance equal to its diameter. Malar space about 0.5 times as long as height of a compound eye. Clypeus almost subquadrate, not sculptured, ventral clypeal margin slightly projected over mandibles. Anterior tentorial pits clearly visible, epistomal sulcus not impressed, clypeo-pleurostomal lines hidden by lateral clypeal striae. Antennal toruli situated at mid height of the head. Distance between antennal rim and compound eye slightly longer than width of antennal socket including rim.

Occiput (Fig. 1B) sparsely pubescent, with alutaceous-reticulate sculpture, without occipital carina. Distance between occipital and oral foramina as long as height of occipital foramen. Hypostomal sulci slightly impressed, joining before hypostomata.

Mouthparts. Mandibles strong, exposed; right mandible with 3 moderately acute teeth; left with 2 teeth. Maxillary stipes twice as long as wide; maxillary palp 5-segmented; labial palp 3-segmented.

Antennae, female (Fig. 1C) with 13 articles; flagellum not broadening apically. Elongate placodeal sensilla present on all flagellomeres except F1 and F2. Length of antennomeres as 19:16:21:16:17:16: 16:16:16:16:15:14:29. Pedicel 1.7 times as long as wide; F1 1.3 times as long as pedicel, slightly curved in the middle but not expanded at apex. Placodeal sensillae long, 3-5 moderately spaced sensillae, disposed in a single row, visible in each flagellomere. Male antenna (Fig. 1D), with 14 antennomeres; F1 more distinctly curved, flattened and slightly expanded distally.

\section{Mesosoma}

Pronotum, female (Fig. 2A). Length of pronotum medially (= shortest distance between dorsal and anterior margins) moderately long (high). Admedian pronotal depressions oval-transverse, separated, usually hidden by the ventral pronotal plate. Lateral surface of pronotum with reticulate sculpture.

Mesonotum. Mesoscutum (Fig. 1E) 1.4 times as wide as long in dorsal view; with reticulate sculpture and with some scattered, short setae. Median mesoscutal impression shallow and inconspicuous in posterior one third of mesoscutum, absent anteriorly. Notauli complete, narrow, not strongly con- 

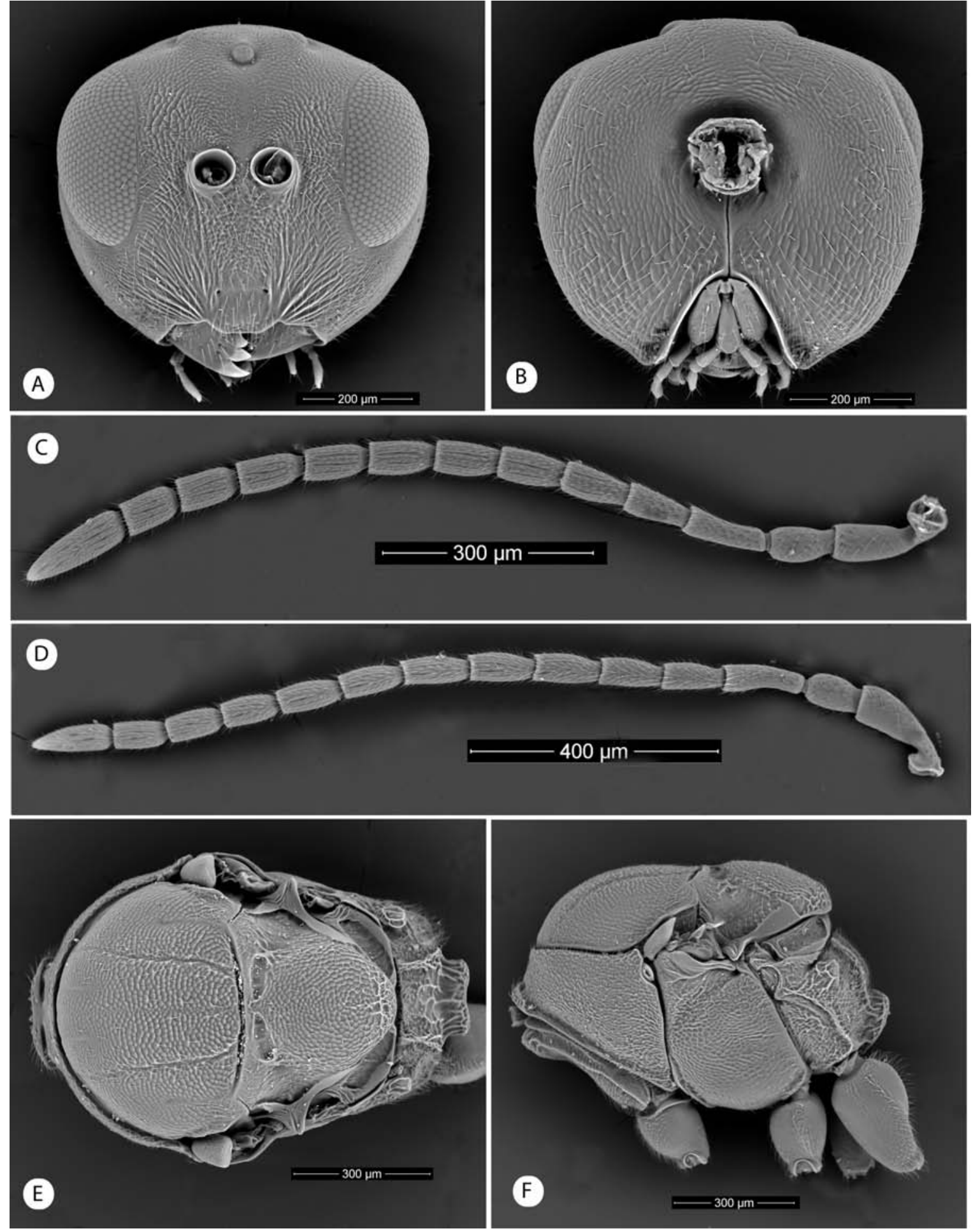

Fig. 1.- Phanacis kiefferi, adult (SEM). (A) Head anterior view; (B) Head posterior view; (C) Female antenna (D) Male antenna; (E) Mesosoma dorsal view; (F) Mesosoma lateral view.

Fig. 1.- Phanacis kiefferi, adulto (SEM). Cabeza en visión anterior (A) y posterior (B); Antena de la hembra (C) y del macho (D); mesosoma en visión dorsal (E) y lateral (F). 

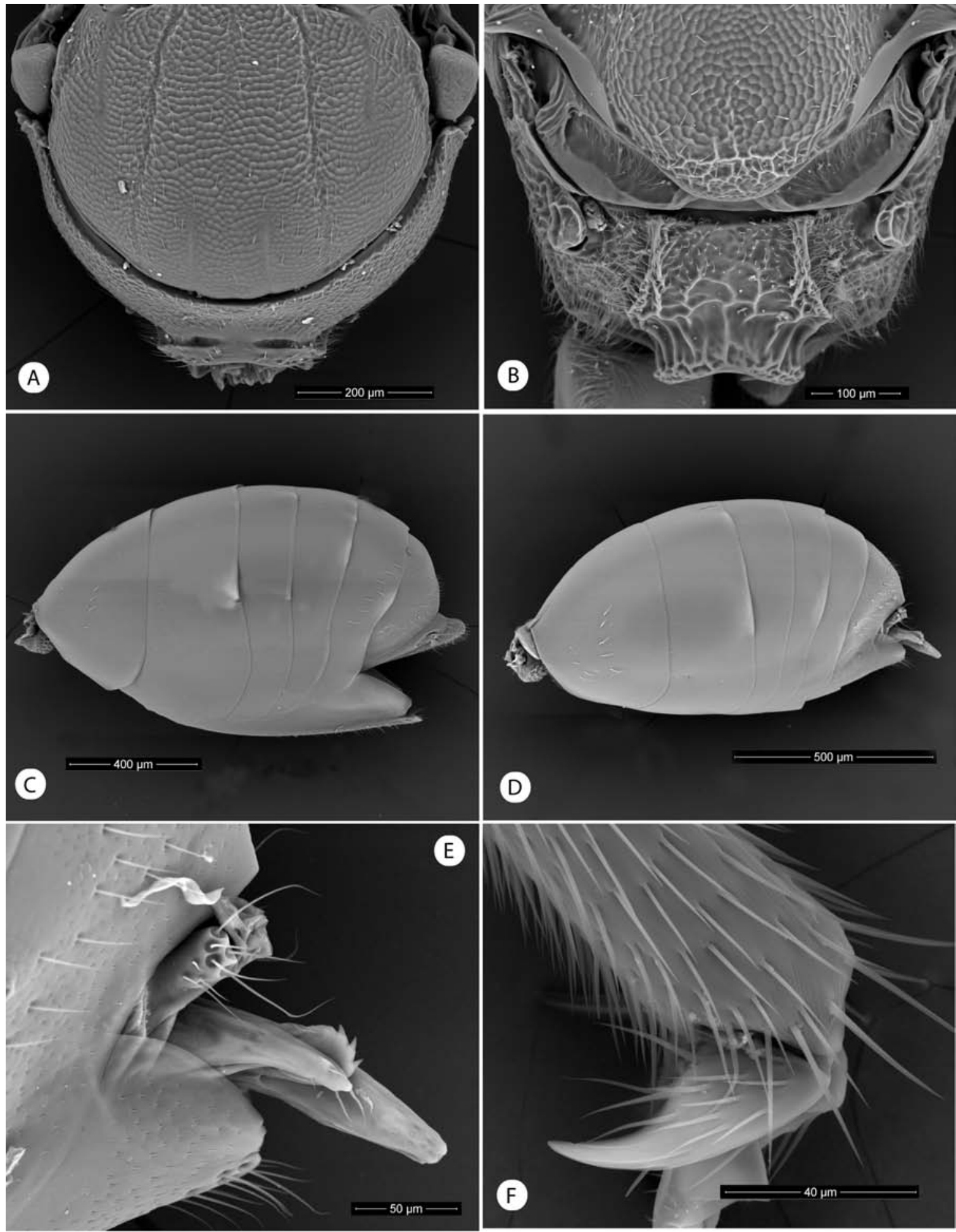

Fig. 2.- Phanacis kiefferi, adult (SEM). (A) Pronotum frontal view; (B) Propodeum; (C) Female metasoma (D) Male metasoma; (E) Terminal abdominal segments and genitalia of male metasoma; (F) Metatarsal claw.

Fig. 2.- Phanacis kiefferi, adulto (SEM). (A) Pronoto en visión dorsal; (B) Propodeo; (C) Metasoma de la hembra; (D) Metasoma del macho; (E) Segmentos abdominales terminales y genitalia del metasoma del macho; (F) Uña metatarsal. 
verging posteriorly; distance between notauli at the transscutal fissure 0.5 as distance at anterior mesoscutal margin (Fig. 1E). Anteroadmedian signa visible but faint. Mesoscutum and scutellum separated by a distinct transscutal suture. Scutellar foveae ellipsoidal, 0.15 times as long as scutellum, foveae smooth; their anterior and posterior margins well marked, the posterior margins widely diverging from a medial septum separating the foveae. Dorsal surface of scutellum with marked reticulate sculpture, rugose posteriorly. Axillula densely pubescent. Mesopleuron beneath mesopleural triangle completely reticulate sculptured (Fig. 1F). Posterior margin of mesopleural triangle not well marked.

Metanotum (Fig. 2B). Metascutellum conspicuously constricted medially. Metanotal trough 1.2 times as wide as medial constriction of metascutellum, smooth and pubescent.

Metapectal-propodeal complex. Lateral propodeal carinae narrow, slightly divergent posteriorly. Lateral and median propodeal area with rugose sculpture and pubescent. Nucha dorsally with strong, irregular, longitudinal rugae.

Legs. Metatibia 1.06 times as long as metatarsus. Tarsal claws (Fig. 2F) simple, without a basal lobe or tooth.

Forewing (Fig. 4B) 0.7 times as long as body, hyaline. Radial cell 2.1 times as long as wide; R1 prolonged along anterior margin of wing, but the vein is much paler, losing its colour; first abscissa of radius (2r) curved and radius (Rs) slightly bowed, reaching anterior margin of wing. Areolet conspicuous. Hair fringe along apical margin of wing long.

\section{Metasoma}

Female metasoma (Fig. 2C) as long as head and mesosoma combined. Third abdominal tergum 0.3 times as long as metasoma; 1.2 times as long as fourth; antero-medial area of third abdominal tergum bearing only 4-5 setae and thus not forming a patch. Fourth to seventh terga smooth, bare, without micropunctures visible, excepting some micropunctures visible basally on fourth tergum. Projecting part of hypopygial spine short, about twice as long as height, with some long setae slightly longer as apical margin of spine. Male metasoma (Fig. 2D) with third abdominal tergum 0.4 times as long as metasoma; 1.6 times as long as fourth; 8 setae present on antero-medial area of third abdominal tergum. Phallus. Aedeagus not expanded apically. Paramere only slightly extending beyond digitus; digitus with three visible spines (Fig. 2E).
Gall (Figs. 4F-H)

The gall develops at the annulus or collar area, between the stem and the root of the host plant Carthamus lanatus L. (Asteraceae), and, therefore, the galls are subterranean or semisubterranean. Gall size is variable, from only small swellings measuring $0.7 \times 0.4 \mathrm{~cm}$, to larger swellings measuring 1.5 x $2.1 \mathrm{~cm}$ (average $=1.2 \mathrm{~cm}$ width $\mathrm{x} 1 \mathrm{~cm}$ length; $\mathrm{N}=15$ ). There is frequently only one swelling in each galled plant stem, but there are occasionally two neighbouring swellings (Fig. 4G) or even several smaller swellings, which coalesce into a larger mass. In addition to the hypertrophied stems, we occasionally find cryptic galls, which are composed of scattered isolated larval cells (Fig. 4E). Each gall is plurilocular (polythalamous), the internal tissue is white and tough, and contains several scattered larval cells. The surface of the galls is rugose and glabrous. The galls develop in spring and mature during the summer, and remain on the dry plants in the late summer.

The original description of the galls collected in France reported the presence of smaller galls developing on the concave sides of branching aerial stems and causing variable deformations on stems or in the median leaf veins. We did not observe any of these types of aerial galls in material collected in Spain.

\section{Remarks}

The original account of Aulacidea kiefferi (attributed by Cotte to Kieffer) consists of a short description and a drawing of a female habitus. Although the species was originally thought to belong to the genus Aulacidea, some morphological characteristics of the original description are not consistent with the characteristics of this genus. For example, the absence of facial striae, and the third antennal segment, clearly longer than the fourth, does not fit with Aulacidea. Another character usually present in Aulacidea species is a lateral patch of dense setae on the base of the second metasomal tergum, but this character is not mentioned in the description of $A$. kiefferi and was not observed in the specimens studied here. Other characteristics described in the original account are further inconsistent. The mesopleuron is described as shiny and nearly smooth, a characteristic that does not fit with either Aulacidea or Phanacis as Aulacidea shows a striated mesopleuron, and Phanacis shows a reticulate sculpture. The closed radial cell is a hallmark of all Aulacidea species, and is shared by some species of the Phanacis/Timaspis complex. In conclusion, after augmenting the original description 

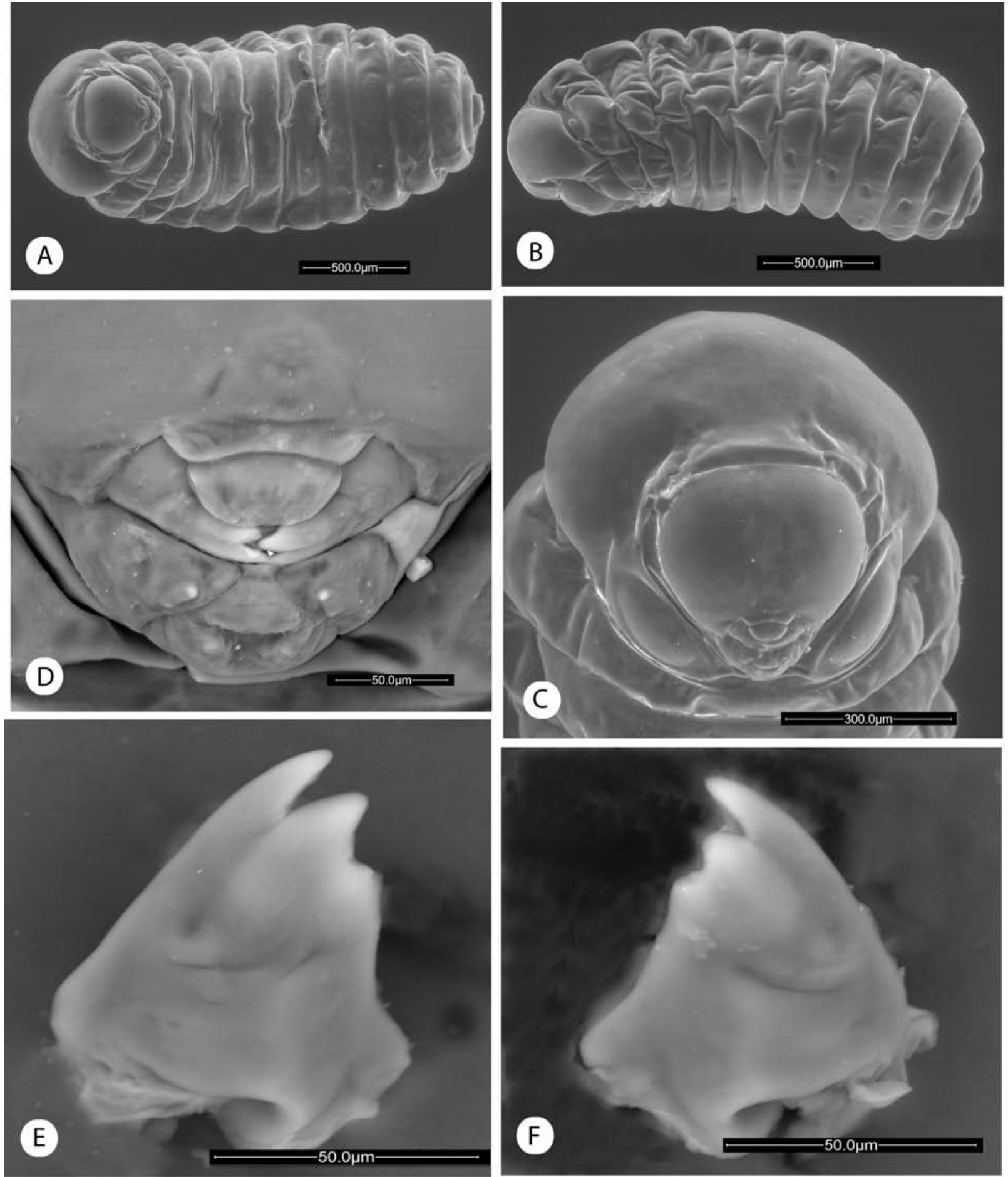

Fig. 3.- Phanacis kiefferi, terminal larva (SEM). (A) Body ventral view; (B) Body lateral view; (C) Head anterior view (D) Detail of mouth parts; (E) Left mandible; (F) Right mandible.

Fig. 3.- Phanacis kiefferi, larva terminal (SEM). (A) Cuerpo en visión ventral; (B) Cuerpo en visión lateral; (C) Cabeza en visión anterior; (D) Detalle de las piezas bucales; (E) Mandíbula izquierda; (F) Mandíbula derecha. 

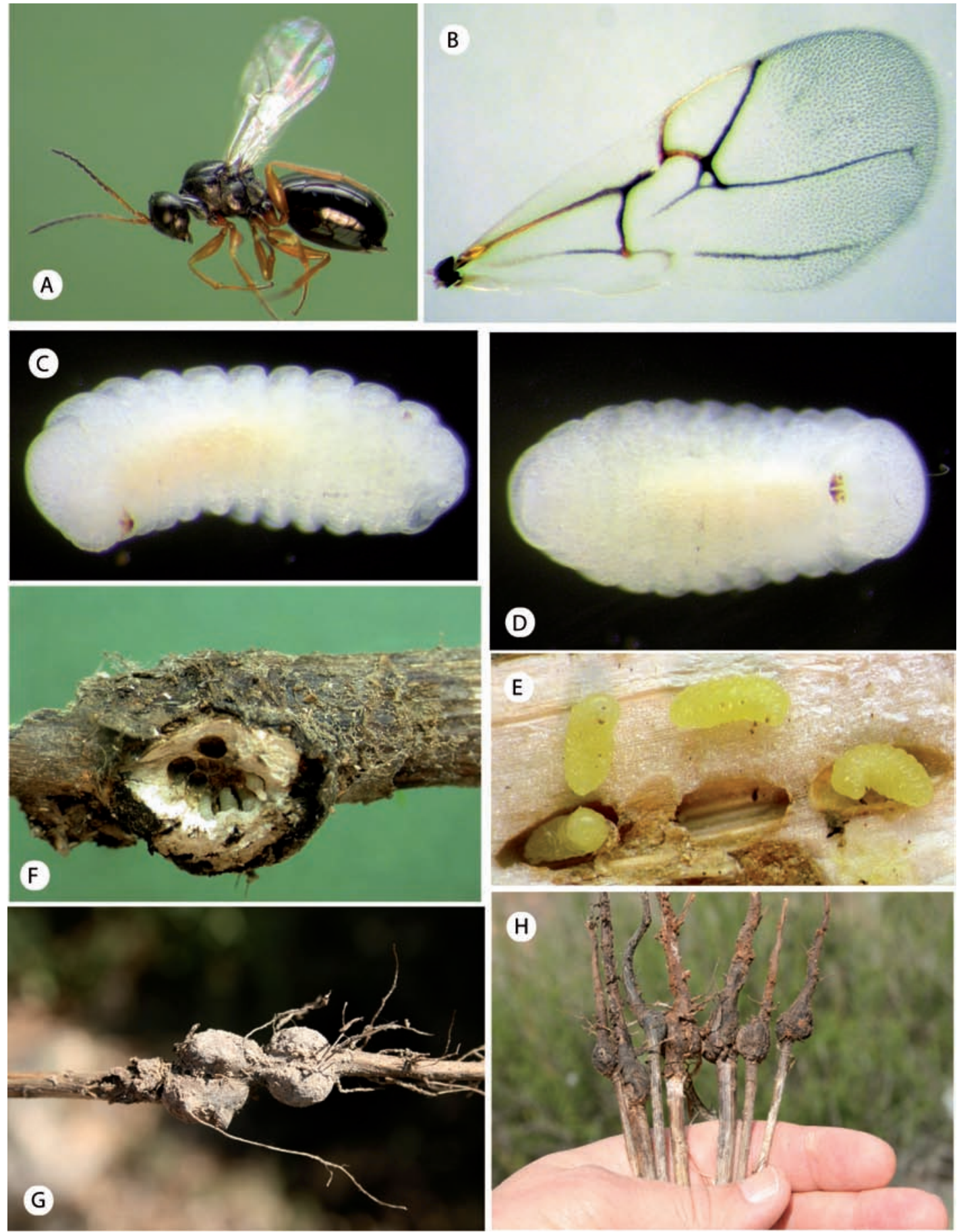

Fig. 4.- Phanacis kiefferi, habitus of the adult, terminal larvae and galls (LM). (A) Habitus female; (B) Forewing; (C) Terminal larva (lateral view); (D) Terminal larva (ventral view); (E), (F) section of a gall showing larvae and larval cells; $(\mathrm{G}),(\mathrm{H}) \mathrm{Mature}$ galls located between the stem and the root of Carthamus lanatus plants (Asteraceae).

Fig. 4.- Phanacis kiefferi, hábitus del adulto, larva terminal y agallas (LM). (A) Hábitus de la hembra; (B) Ala anterior; (C) Larva terminal en visión lateral; (D) Larva terminal en visión ventral; (E-F) Sección de una aglla mostrando las celdas larvales y las larvas; (G-H) Agallas maduras situadas entre el tallo y la raíz de plantas de Carthamus lanatus (Asteraceae). 
with additional characters from our recently collected material, including the conformation of the pronotum and the larval morphology, we are confident that this species belongs to the genus Phanacis.

Morphologically Phanacis kiefferi is similar to Phanacis zwoelferi Nieves-Aldrey, 1995, a species inducing cryptic galls in stems of Silybum marianum L. However, the proportions of antennal segments, the shape of the scutellar foveae, and the coloration of R1 along the anterior margin of the radial cell, allow easy differentiation between the two species. P. kiefferi is readily distinguished from the species $P$. helminthiae (De Stefani, 1902), $P$. caulicola (Hedicke, 1939) and P. comosae NievesAldrey, 2008 by the non sculptured clypeus, projected ventral margin of clypeus, the shallow, narrower posteriorly notauli, and the relatively shorter radial cell.

The group of Phanacis species related to P. kiefferi can be distinguished with the key as follows.

Key to West European species of Phanacis related to P. kiefferi

1. Radial cell closed on margin; vein $\mathrm{R} 1$ is occasionally depigmented along apical margin. Notauli shallow, narrow posteriorly and usually faint anteriorly; median mesoscutal impression short. Clypeus almost smooth, without longitudinal rugae. The first five antennal segments with a lighter color than rest of antennal flagellum

- Radial cell completely or partially open on apical margin. Notauli percurrent, wider and deeply impressed posteriorly; median mesoscutal impression long. Clypeus with strong longitudinal rugae. Antenna uniformly dark brown or the complete antennal flagellum contrasting in color with scape and pedicel

2. Antenna short, slightly longer than combined length of head and mesosoma. Scutellar foveae confluent and shallow, opening laterally with regular longitudinal striae. Radial cell 2.5 times as long as wide, completely closed on margin; vein R1 pigmented along margin of wing; areolet small. Male brachypterus, showing lighter coloration than females. Galls cryptic in stems of Centaurea species ...... P. centaureae

- Antennae clearly longer than combined length of head and mesosoma. Scutellar foveae closed laterally, without longitudinal striae. Radial cell 2.1-2.3 times as long as wide, vein R1 less pigmented apically; areolet larger. Male with normal wings and similar black coloration as females. Galls found on stems of Silybum marianum or roots of Carthamus lanatus 3
3. Scutellar foveae large, rounded, shallow, confluent at inner margins and with posterior margins not marked. F1 four times as long as wide; 1.5 times as long as pedicel. R1 pigmented basally and un-pigmented along posterior half of apical margin. Galls cryptic in stems of Silybum marianum and Notobasis syriaca ............................................. P. zwoelferi

- Scutellar foveae smaller, oval and deeper, with posterior margins well marked. F1 three times as long as wide; 1.3 times longer as pedicel. vein R1 un-pigmented along entire margin of radial cell. Galls on roots of Carthamus lanatus P. kiefferi

4. Radial cell twice as long as wide; R1 un-pigmented only along apical margin of radial cell. Antennal flagellum not contrasting in color, with scape and pedicel. Galls conspicuous in stems of Hypochoeris spp.

\section{P. hypochoeridis}

- Radial cell 2.5 times as long as wide; R1 almost completely un-pigmented along margin of radial cell; radial cell appearing open on margin. Antennal flagellum contrasting in color, with scape and pedicel. Galls in stems or flower heads of Picris species ...... P. caulicola, P. helminthiae and P. comosae See key for their identification in Nieves-Aldrey et al (2008).

\section{Life cycle}

This species shows a typical single brooded sexual generation life cycle. Insects emerge from the galls in the spring of the second year, when new host plants are available. The sex ratio is not even, males appearing at a lower frequency than females ( 3 out of 51 individuals in the present study).

\section{FINAL INSTAR LARVA (Figs. 3A-F)}

Material examined: Spain, Madrid, Arganda del Rey, 09/XI/2008 ex galls in stems of Carthamus lanatus, J.L. Nieves leg $(\mathrm{n}=8)$.

Description. Length $2.4 \mathrm{~mm}$ (range 2.3-2.6; $\mathrm{n}=$ $5)$. Body in ventral and lateral views sub-rectangular (Figs 3A-B), weakly and gradually tapering towards the posterior end; relatively straight and only slightly curved ventrally. Integument yellowish and smooth, with a few short setae concentrated in the head region and the first thoracic segment. Body composed of head and 13 segments. First segment, in ventral view divided into two parts, one dorsal and the other ventral, separated by a constriction or a suture; anterior and posterior margins of ventral part of this first body segment touching at the ventral-most point, below mouth parts; segments 6-11 of similar length but progressively narrower; last segment truncate at apex and wider than long.

Head (Fig. 3C) more or less triangular, medial area of vertex convex. Antennal areas and antennae 
not visible. Antennal setae absent. A pair of very short and inconspicuous genal setae present.

Mouthparts. Clypeus (Fig. 3D) well marked with its ventral margin straight and clearly prolonged ventrally into a sub-rectangular piece above the labrum; pair of supraclypeal setae present. Labrum more or less semicircular with regularly curved sides. Maxillae triangular with its apex pointed and with a pair of conspicuous maxillary palps. Tip of mandibles visible under labrum. Maxillary setae present but inconspicuous. Labium small and concavous, usually collapsed. Salivary opening rounded and situated under a funnelshaped depression; the area surrounding the salivary opening is tuberculate and not clearly visible.

Mandibles (Figs 3E-F) slightly asymmetrical, without sculpture or hairs. Both mandibles with two teeth and a third secondary smaller tooth; the intermediate tooth being shorter on the right mandible.

Distribution. This species was originally recorded only from a single location on the Mediterranean coast of France (Cote d'Azur,Var, Cogolin). The species is now found in Arganda (Madrid), Central Spain.

\section{Discussion}

In addition to $P$. kiefferi, three cynipid species have been recorded as galling Carthamus species (Melika, 2006). Phanacis carthami Gussakovskij, 1933 was found on roots of Carthamus sp.; Isocolus carthami Diakontschuk, 2003 induces galls in flower heads of Carthamus lanatus L., and Isocolus tinctorius Melika \& Gharaei, 2006, induces galls in flower heads of Carthamus tinctorius L. Phanacis carthami has been recorded in Uzbekistan and Ukraine, while I. carthami is known from Ukraine and I. tinctorius from Iran. Of these three species, $P$. carthami is the most closely related to $P$. kiefferi. Despite the fact that the specific host plant species has not been identified (Carthamus sp.), both the generic description and the subterranean location of the gall of this species closely resemble P. kiefferi. However, the descriptions of the galls do not match: P. carthami galls are described as monolocular, and sometimes form aggregates in roots as deep as seven $\mathrm{cm}$ (Belizin, 1959; Melika, 2006), while P. kiefferi galls are plurilocular and usually located at the ring region, between the root and the stem. Furthermore, according to the identification key by Melika
(2006), P. carthami adults differ from P. kiefferi individuals in the shape of the scutellar foveae, the notauli, as well as in coloration.

The host plant Carthamus lanatus L. (the saffron or distaff thistle) is an annual plant native to the Mediterranean Region, which now presents a virtually worldwide distribution. In large areas of North America and Australia, it is a widespread and troublesome weed of crops and pastures (Aeschlimann, 1997; Ash et al, 2003). In Spain, this plant is common in refuse areas, along paths, ditches, dumps, uncultivated and wastelands. In central Spain and to the southeast of Madrid, this plant is frequent in dry areas with calcareous soils. The habitat is shared with other plants of the family Asteraceae, including Silybum marianum, and Centaurea spp., other hosts of Phanacis species (sensu stricto).

A large survey of natural enemies of $C$. lanatus was performed in southern Europe (Aeschlimann, 1997). However P. kiefferi was not cited among the 50 different natural enemies discussed. P. kiefferi might potentially be used as agent for the biological control of this harmful weed.

\section{ACKNOWLEDGEMENTS}

Financial support for this paper was provided by the Spanish Ministry of Education and Science, research project CGL2005-01922/BOS. I thank Marta Furió for technical assistance in the production of the SEM photographs. I am also grateful to Olivier Plantard and Jerry Bowdrey for their useful comments on the manuscript.

\section{References}

Aeschlimann, J. P., 1997. Reappraising the potential of biological control against the weed Carthamus lanatus. Entomophaga, 42(4): 559-568.

Ash, C. J., Raman, R. \& CRump, N. S., 2003. An investigation of genetic variation in Carthamus lanatus in New South Wales, Australia, using intersimple sequence repeats (ISSR) analysis. Weed Research, 43: 208-213.

Belizin, V. I., 1959. [Gall wasps of the tribe Aylaxini (Hymenoptera, Cynipoidea) new for the fauna of the U.S.S.R.] Entomologicheskoye Obozreniye, 38: 662674 [in russian].

Cotte, J., 1915. Observations sur quelques cécidozoairés. Annales du Muséum d'Histoire Naturelle de Marseille, 15(2): 5-36.

EADY, R. D. \& Quinlan, J., 1963. Hymenoptera: Cynipoidea. Key to families and subfamilies and Cynipinae (including galls). Handbooks for the identification of British Insects, 8(1a): 1-81. 
Liljeblad, J., 2002. Phylogeny and Evolution of Gall Wasps (Hymenoptera: Cynipidae). Doctoral dissertation. Department of Zoology, Stockholm University. $36 \mathrm{pp}$.

LilJeBlad, J. \& Ronquist, F., 1998. A phylogenetic analysis of higher-level gall wasp relationships (Hymenoptera: Cynipidae). Systematic Entomology, 23: 229-252.

MeliKa, G., 2006. Gall wasps of Ukraine. Cynipidae, vol. 1. Schmalhausen Institute of Zoology. Nacional Academy of Sciences of Ukraine. Kiev. 300 pp.

MeliKa, G. \& Prinsloo, G. L., 2007. Phanacis naserorum sp. n. (Hymenoptera: Cynipidae: Aylacini): first record of a phytophagous Afrotropical cynipoid gall wasp. African Entomology, 15(1): 185-191.

Nieves-AldRey, J. L., 1994. Revision of West-European Genera of the Tribe Aylacini Ashmead (Hymenoptera, Cynipidae). Journal of Hymenoptera Research, 3:175-206

Nieves-Aldrey, J. L., 2001. Hymenoptera, Cynipidae. In: Fauna Ibérica, vol. XVI. Ramos, M.A. et al (eds.). Museo Nacional de Ciencias Naturales. CSIC. Madrid. 636 pp.

Nieves-Aldrey, J. L., SÁnchez, I., Massa, B. \& GÓmez, J. F., 2008. Cynipid wasps that induce galls on plants of the genus Picris (Asteraceae) in Europe, with a description of a new species of Phanacis Foerster (Hymenoptera, Cynipidae) from the Iberian Peninsula. Annales de la Société Entomologique de France, 44(3): 257-269.

Nieves-Aldrey, J. L., VÅrdal, H. \& Ronquist, F., 2005. Comparative morphology of terminal-instar larvae of Cynipoidea: phylogenetic implications. Zoologica Scripta, 34: 15-36.
Nylander, J. A. A., Ronquist, F., Huelsenbeck, J. P. \& NieVes-Aldrey, J. L., 2004 Bayesian phylogenetic analysis of combined data. Systematic Biology, 53: 47-67.

RONQUIST, F., 1995. Phylogeny and early evolution of the Cynipoidea (Hymenoptera). Systematic Entomology, 20: 309-335.

RonQuist, F. \& LilJeBlad, J., 2001. Evolution of the gall wasp-host plant association. Evolution, 55: 25032522.

RoNQuist, F. \& NoRDLANDER, G., 1989. Skeletal morphology of an archaic cynipoid, Ibalia rufipes (Hymenoptera: Ibaliidae). Entomologica Scandinavica, Supple-ment 33: 1-60.
Recibido, 25-IX-2008
Aceptado, 18-XI-2008
Publicado, 29-XII-2008 
